\title{
The role of biologic techniques in improving the life state of flowering shrubs
}

\author{
Marina Dogadina * \\ FSBE IHPE "Orel state agrarian University named after N.V. Parahin» Rodina, 69, Orel, 302019, \\ Russia.
}

\begin{abstract}
The key to the normal growth and development of flowering shrubs is to provide optimal living conditions in the juvenile period. Obtaining high-quality planting material in a nursery using biologized techniques is a fundamental component of their future resistance to a complex of abiotic and biotic factors. The use of vermicompost ( $6 \mathrm{t} / \mathrm{ha})$ as a fertilizer base and biologically active substances contributed to the production of high-quality seedlings. The applied biologic techniques contributed to the improvement of the growth and development of flowering shrubs, which influenced the reduction of damage by pests and diseases, the formation of healthy, decorative and attractive plants. Based on the analysis of the vital state, we ranked flowering shrubs according to their prospects for use in landscape design of the territory of urban ecosystems. Promising species for landscaping urban ecosystems in terms of a set of indicators are: Berberis thunbergii DC., Chaenomeles japonica (Thunb.) Lindl.), Lonicera caprifolium L., Physocarpus opulifolius L., Philadelphus coronaries L., Sorbaria sorbifolia L., Syringa velutina L. u Weigela florida DC.
\end{abstract}

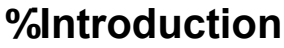

In the greening of the modern city, the leading role belongs to flowering shrubs. They acquire special significance in landscape design due to their high decorative and artistic value, a wide range of colors of flowers and foliage, a different and long period of flowering, a short period of formation in the initial period of growth $[1,2]$. Due to the high decorativeness, the brightness of the colors, they have a beneficial effect on the psychological state of a person, relieving stress. By releasing phytoncides into the environment, which have antibacterial, protistocidal, antifungal properties, flowering shrubs create a favorable microclimate of the urban area $[3,4]$. But, in turn, the urban environment, being a powerful stressor for the biocenosis, causes irreparable damage, detrimental effect on flowering shrubs, reducing their decorative effect, attractiveness, productivity, gives rise to non-infectious diseases, reduces the overall resistance of plants to damage by pests, phytopathogens, makes them vulnerable

\footnotetext{
*Corresponding author: marinadogadina@yandex.ru
} 
to the effects of abiotic factors. Unfavorable weather and climatic conditions, which have recently become more frequent, sharp changes in temperature and water regimes reduce the adaptive reactivity of plants. Of no small importance is the quality of the substrate on which the plants grow. Urbanozems contain an insignificant amount of nutrients, have low mechanical characteristics, which are manifested in poor water-air capacity, include construction waste, toxic elements, substances and compounds that emit from the work of industrial enterprises, exhaust gases from cars $[5,6,7]$. Consequently, for landscape design, an assortment of flowering shrubs is required, characterized by a high degree of resistance to a complex of adverse factors, adapted to growing conditions. The fundamental components of resistance must be laid at the initial stages of plant growth and development, i.e. in a nursery. Qualitatively grown planting material of introduced plants will further reduce the environmental risks of using agrochemicals and means of protection, and improve the living condition [8-12]. The objectives of the study included an analysis of the vital state of flowering shrubs grown using traditional and biologized technology; assessment of damage to flowering shrubs by entomo- and phytopathogenic objects in an urbanized environment. The aim of the research is to form an adapted range of flowering shrubs for the conditions of urban ecosystems.

\section{पMaterials and research methods}

Studies to identify an adapted range of flowering shrubs for the conditions of urban ecosystems were carried out in 2017-2019. The object of the study was three-year-old flowering shrubs used as an additional assortment in the landscape design of urban ecosystems: berberis Tunberg (Berberis thunbergii DC.), blood-red hawthorn (Crataegus sanguinea Pall.), weigela florid (Weigela florida DC.), hydrangea large-leaved (Hydrangea macrophylla (Thunb.) Ser.), goat-leaf honeysuckle (Lonicera caprifolium L.), prairieweed (Potentilla fruticosa L.), trailing mahonia (Mahonia aquifolium (Pursh) Nutt.)), almond (Prunus dulcis L.), dwarf ninebark (Physocarpus opulifolius L.), schizonotus (Sorbaria sorbifolia L.), common lilac (Syringa vulgaris L.), hungarian lilac (Syringa josikaea L.), velutinous lilac (Syringa velutina L.), spiraea Bumal'da (Spiraea bumalda Burv.), Philadelphus coronarius L., Japanese quince (Chaenomeles japonica (Thunb.) Lind1.)). For the study, flowering shrubs were used, grown according to traditional technology and using biologic techniques (vermicompost was introduced into the soil of the experimental site before planting rooted cuttings of plants $-6 \mathrm{t} / \mathrm{ha}$, obtained on the basis of sewage sludge, ash and buckwheat husks, during the growing season, treatments were carried out with biologically active substances: Mival-Agro (0.3\%), Novosil ( $0.1 \%)$; Fitoverm $0.2 \%$ e.c. and Alirin-B, w.p. was used to protect against harmful objects. Experimental options: 1. Control. 2. Vermicompost (6 t / ha) + Mival-Agro (10 g/ ha), Novosil ( $0.21 /$ ha), Fitoverm, $0.2 \%$ e.c. $(81 /$ ha $)+$ Alirin-B, w.p. $(0.6 \mathrm{~kg} / \mathrm{ha})$. A route survey of green spaces in the city of Orel was completed.

$$
\text { Vitality Index: } V I=\frac{100 n 1+70 n 2+40 n 3+5 n 4}{\mathrm{~N}}
$$


where $V I$-forest stand vitality index; $\mathrm{n}_{1}$ - number of healthy (no signs of weakening) shrubs, $\mathrm{n}_{2}$ - weakened, $\mathrm{n}_{3}$ - severely weakened, $\mathrm{n}_{4}$-dying; 100, 70, 40, 5 - coefficients expressing (in percent) the relative vital state of healthy, weakened, heavily weakened and dying shrubs, respectively; $\mathrm{N}$ - the total number of shrubs (including dead trees). The assessment of the harmfulness of diseases was carried out on a 5-point scale: 0 - healthy plant; 1 - weak damage to an organ or plant; 2 - the lesion is average, severely affected organs are not found; 3 - the lesion is medium, some organs or plants are severely affected; 4 - severe damage to organs or plants, death. To assess the damage by sucking pests, the plants were examined by examining 50-100 leaves at different points of the crown. When determining the density of pest colonization, a point scale was used (for adults on one leaf and average population density on the plant): 0 - there are no pests; 1 - low population density, up to 5 individuals; 2 - average population, up to 30 individuals; 3 - 31-50 individuals; 4 - more than 50 individuals.

\section{$\square \square$ Research results and their discussion}

According to some authors $[13,14]$, many flowering shrubs are relatively unpretentious and resistant. Other researchers hold the opposite opinion and note that due to the deterioration of the ecological situation over the past 20-30 years, ornamental flowering shrubs began to be exposed to various diseases [15]. It should also be noted the emerging susceptibility of flowering shrubs to the effects of adverse environmental factors and damage by pests. A decrease in plant resistance to a complex of unfavorable factors is associated with the conditions of the urban environment that are aggressive for plants: dustiness and gas content of the atmosphere, pollution of the hydro- and pedosphere, halogenesis processes, high density of communal devices located in the root layer, imbalance in power supply elements, as well as low-quality characteristics of artificial soil, including various building impurities, using weakly resistant plants for landscaping purposes. An analysis of the life state of flowering shrubs in an urbanized environment (for example, the city of Oryol), based on a comprehensive assessment of standardized parameters, is shown in Figures 1-5. 


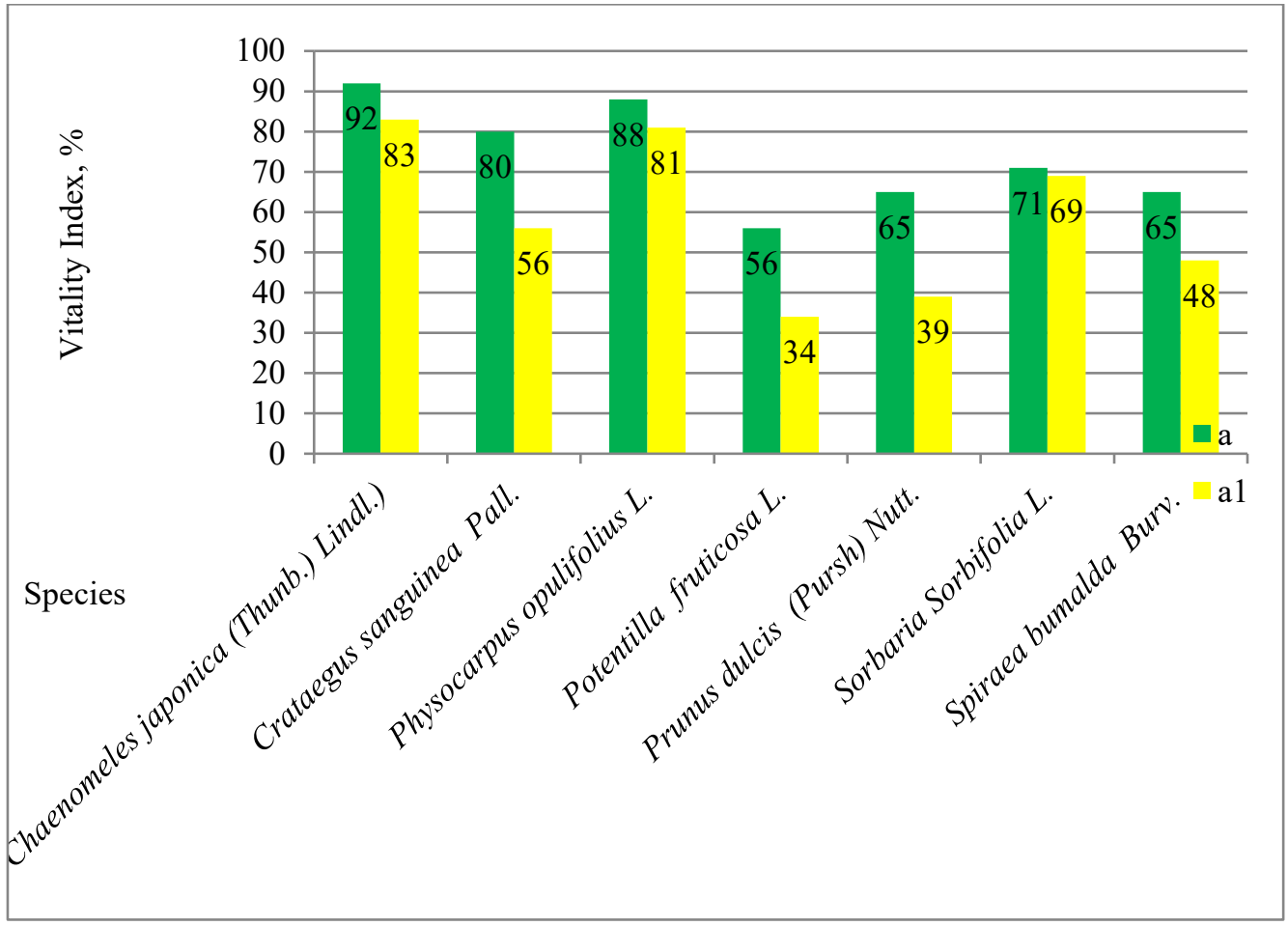

$\mathrm{a}^{*}$ - shrubs grown using biologized techniques;

$\mathrm{a}_{1}{ }^{*}$ - shrubs grown according to traditional technology

Fig. 1. Analysis of the life state of flowering shrubs of the Rosaceae family in an urbanized environment (for example, the city of Oryol).

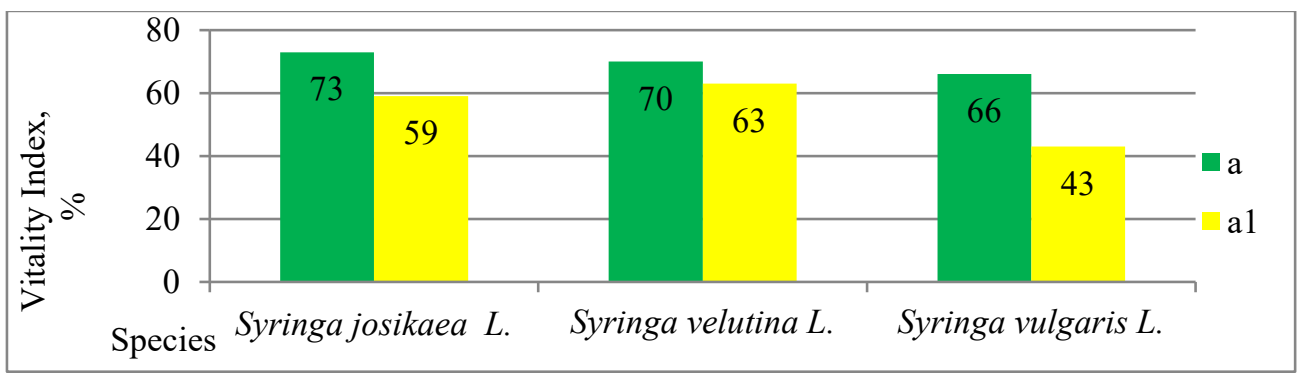

Fig. 2. Analysis of the vital state of flowering shrubs of the Oleaceae family in an urbanized environment (for example, the city of Oryol).

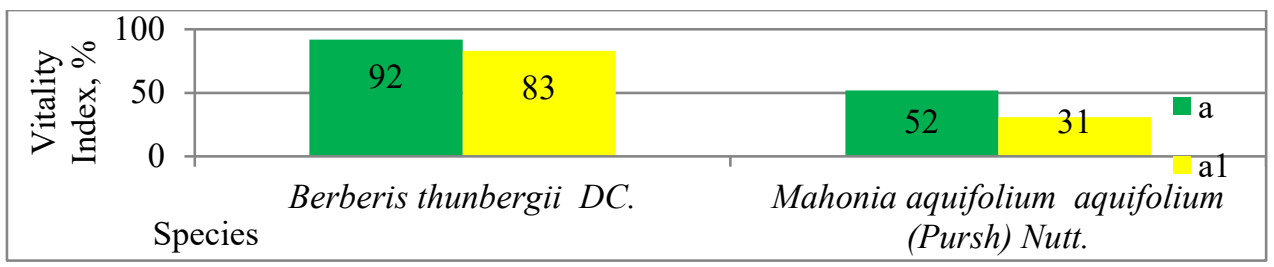

Fig.3. Analysis of the vital state of flowering shrubs of the Berberidaceae family in an urbanized environment (for example, the city of Oryol). 


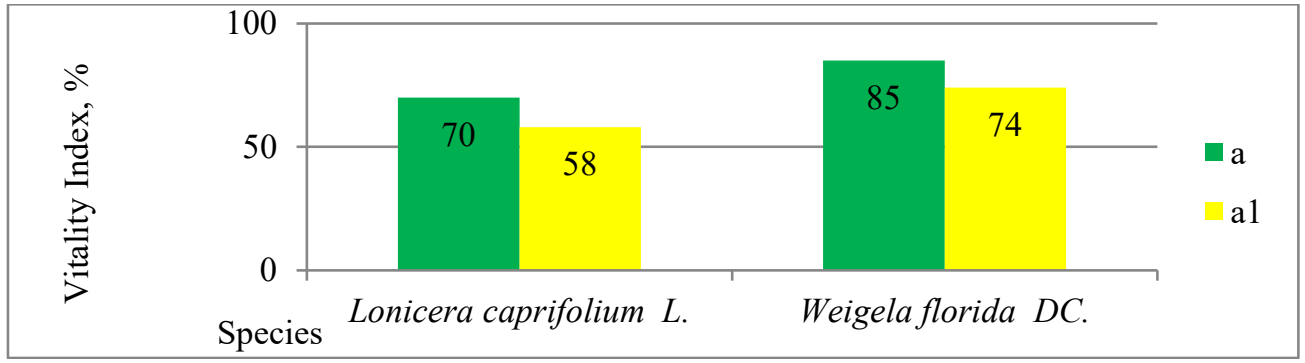

Fig.4. Analysis of the life state of flowering shrubs of the Caprifoliaceae family in an urbanized environment (for example, the city of Oryol).

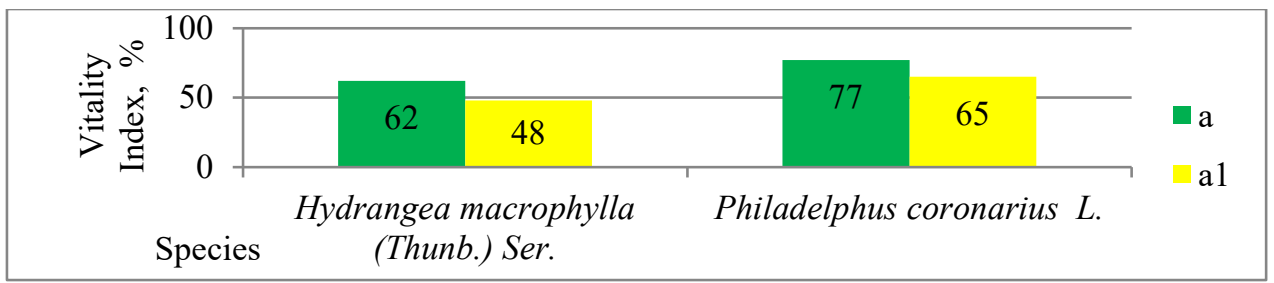

Fig.5. Analysis of the vital state of flowering shrubs of the family Hydrangeaceae in an urbanized environment (for example, the city of Oryol).

As can be seen from Figures 1-5, the conditions of the urbanized environment have a negative effect on flowering shrubs: Hydrangea macrophylla (Thunb.) Ser., Mahonia aquifolium (Pursh) Nutt., Potentilla fruticosa L., Prunus dulcis (Pursh) Nutt., whose vital status index ranged from $56 \%$ to $65 \%$. These shrubs are classified as weakened stands. The species of flowering shrubs, which are highly resistant to aggressive abiotic and biotic factors of the urban environment, have been identified: Berberis thunbergii DC., Physocarpus opulifolius L. и Weigela florida DC. No signs of disease and damage by pests, high decorative qualities, a high index of the vital state convincingly indicates the high responsiveness of plants to the applied biologic techniques.

In recent years, the species composition of pests has diversified, the harmfulness of phytophages, which previously had no significant significance, increased. The emergence of new and the spread of aboriginal species is associated with perennial multi-species plantings, enabling the formation, reproduction, distribution and accumulation of the phytophagous population; the lack of measures for the formation of plantings in an urbanized environment; decrease in plant resistance under the influence of anthropogenic factors; violation of the ecological state of urban ecosystems.

Beautifully flowering shrubs were damaged by sucking pests: Liosomaphis berberidis Kalt, Aphis pomi Deg., Archips rosana L., Pterochloroides persicae Choi., Tetranychus urticae C. L. Koch., Archips rosana L., Gracilaria syringella (F.), Eriophyes saalasi Lipo with a population density of the bushes from 0.6 to 3.5 points. Under the influence of sucking pests, which represent the greatest danger, the decorative effect of flowering shrubs is sharply lost, growth and development are inhibited, the physiological state of plants, flowering is disturbed, frost resistance, thermal and drought resistance decreases, the status of their life state changes. Sucking pests are carriers of viral diseases. A weakened plant is more intensely exposed to various stress factors of the surrounding urban environment, a complex of noninfectious and infectious diseases.

Our research had shown that plants Chaenomeles japonica (Thunb.) Lindl.), Mahonia aquifolium (Pursh) Nutt., Physocarpus opulifolius L., Potentilla fruticose L. and Sorbaria 
sorbifolia L. we're not damaged by pests. Flowering shrubs were less resistant to pests in the urban environment: Syringa vulgaris L., Syringa josikaea L., Syringa velutina L. Infectious diseases cause a number of factors that enhance their effect in the urban environment: extreme weather conditions, depletion and pollution of urban soils, exposure to toxic gases, as well as admixtures of solid substances in the air: tire dust, soot, coal, etc., which settle on plants, impair various physiological and biochemical processes.

The direct action of pollutants leads to a decrease in plant resistance as a whole, premature drying of leaves, and a decrease in decorativeness and productivity. A weakened plant becomes more susceptible to infection, this is the indirect effect of the action of pollutants. Non-infectious diseases dominated on flowering shrubs used in urban greening: chlorosis and hexenbesen, infectious: spots, powdery mildew, rust (Table 1).

Plants Chaenomeles japonica (Thunb.) Lindl., Physocarpus opulifolius L. and Sorbaria sorbifolia L. we're not affected by diseases. Diseases on the rest of the shrubs were dominant: powdery mildew and phyllostictosis. A high score for powdery mildew was observed in Berberis thunbergii DC plants. - 3.3; Syringa josikaea L. 2.6; Syringa velutina L. - 2.1. Phylostictosis on Philadelphus coronarius L. plants -2.2 points. It should be noted the high score of damage to Hydrangea macrophylla (Thunb.) Ser. chlorosis.

Table 1. Damage to flowering shrubs by phytopathogenic objects.

\begin{tabular}{|c|c|c|}
\hline Type of plant & Disease & $\begin{array}{c}\text { The degree } \\
\text { of damage to } \\
\text { the bushes, } \\
\text { points }\end{array}$ \\
\hline $\begin{array}{l}\text { Berberis thunbergii } \\
\text { DC. }\end{array}$ & $\begin{array}{l}\text { Mildew (Microsphaera berberidis Lev.) } \\
\text { Stem rust (Puccinia graminis Pers.) } \\
\text { Phyllosticta leaf spot (Phyllosticta berberidis } \\
\text { Sacc. et Roum.) } \\
\text { Brown spot (Monochaetia berberidicola Pers) } \\
\text { leaf spot (Ascochyta berberidina Sacc., Septoria } \\
\text { berberidis Niessl) } \\
\text { Phyllosticta leaf blight (Phyllosticta berberidicola } \\
\text { Speg.) } \\
\text { Fumago leaf (Fumago vagans } \text { Pers) }\end{array}$ & $\begin{array}{l}3,3 \\
0,6 \\
0,9 \\
0,9 \\
0,1 \\
0,3 \\
0,1\end{array}$ \\
\hline $\begin{array}{l}\text { Crataegus sanguinea } \\
\text { Pall. }\end{array}$ & $\begin{array}{l}\text { Mildew (Podosphaera clandestina var. } \\
\text { clandestina) } \\
\text { Hawthorn rust (Gymnosporangium confusum } \\
\text { Plowr.) } \\
\text { Phyllosticta leaf spot } \\
\text { Allesch.) }\end{array}$ & $\begin{array}{l}1,5 \\
0,9 \\
1,1\end{array}$ \\
\hline $\begin{array}{l}\text { Hydrangea } \\
\text { macrophylla } \\
\text { (Thunb.) Ser. }\end{array}$ & $\begin{array}{l}\text { Sclerotinia disease (Sclerotinia sclerotiorum (Lib) } \\
\text { de Baгy) } \\
\text { Powdery mildew (Erysiphales spp) } \\
\text { Rust (Puccinia spp) } \\
\text { Septoria spot (Septoria spp) } \\
\text { Botrytis (Botrytis cinerea Fr.) } \\
\text { Chlorosis (дисбаланс элементов питания) }\end{array}$ & $\begin{array}{l}0,6 \\
1,2 \\
0,9 \\
0,3 \\
0,3 \\
2,1 \\
\end{array}$ \\
\hline
\end{tabular}




\begin{tabular}{|c|c|c|}
\hline $\begin{array}{l}\text { Lonicera caprifolium } \\
\text { L. }\end{array}$ & $\begin{array}{l}\text { Ramularia leaf spot (Ramularia betae Rostr.) } \\
\text { Cercospora (Cercospora beticola Sacc.) } \\
\text { Mildew (Microsphaera onicerae Lev. var.) } \\
\text { Mottle disease (Caprifolium mottle virus) }\end{array}$ & $\begin{array}{l}1,4 \\
0,9 \\
1,6 \\
0,3\end{array}$ \\
\hline $\begin{array}{l}\text { Mahonia aquifolium } \\
\text { aquifolium (Pursh) } \\
\text { Nutt. }\end{array}$ & $\begin{array}{l}\text { Mildew (Sphaerotheca pannosa Lev. var.) } \\
\text { Rust (Puccinia graminis Pers.) }\end{array}$ & $\begin{array}{l}0,9 \\
0,2\end{array}$ \\
\hline $\begin{array}{l}\text { Philadelphus } \\
\text { coronarius L. }\end{array}$ & $\begin{array}{l}\text { Phyllosticta leaf blight (Phyllosticta vulgaris Ph. } \\
\text { lonicerae), Phyllactinia guttata (Wallr.), } \\
\text { Phyllosticta coronate) } \\
\text { Ascochyta-leaf spot (Ascochyta philadelphi) } \\
\text { Septoria spot (Septoria philadelphi Ell. et Ev.) }\end{array}$ & $\begin{array}{l}2,2 \\
1,1 \\
1,3\end{array}$ \\
\hline $\begin{array}{l}\text { Potentilla fruticosa } \\
\text { L. }\end{array}$ & Rust (Puccinia spp) & 0,6 \\
\hline $\begin{array}{ll}\text { Prunus } & \text { dulcis } \\
\text { (Pursh) Nutt. } & \end{array}$ & $\begin{array}{l}\text { Botritis disease (Botrytis cinerea Fr.), } \\
\text { Cercospora leaf spot }\end{array}$ & $\begin{array}{l}1,1 \\
0,2\end{array}$ \\
\hline $\begin{array}{l}\text { Spiraea bumalda } \\
\text { Burv. }\end{array}$ & $\begin{array}{l}\text { Mildew (Erysiphe syringae Schwein) } \\
\text { Septoria spot (Septoria syringae Berk.) }\end{array}$ & $\begin{array}{l}1,4 \\
0,4\end{array}$ \\
\hline $\begin{array}{l}\text { Syringa vulgaris } \mathrm{L} . \\
\text { Syringa josikaea } \mathrm{L} . \\
\text { Syringa velutina } \mathrm{L} .\end{array}$ & $\begin{array}{l}\text { Mildew (Erysiphe syringae Schwein) } \\
\text { Septoria spot (Septoria syringae Berk.) } \\
\text { Phyllosticta leaf blight (Phyllosticta syringae } \\
\text { Sacc. et Roum.) } \\
\text { Ascochyta-leaf spot (Ascochyta syringae) } \\
\text { Ring spot (Lilac ringspot virus) } \\
\text { Vascular disease (Verticillium albo-atrum) } \\
\text { Hexenbesen }\end{array}$ & $\begin{array}{l}1,2 / 2,6 / 2,1 \\
0,9 / 1,1 / 1,1 \\
0,2 / 0,2 / 0 \\
0 / 0,3 / 0 \\
0,4 / 0 / 0 \\
0,8 / 0,8 / 0,4 \\
0,3 / 0,2 / 0\end{array}$ \\
\hline Weigela florida DC. & $\begin{array}{l}\text { Rust (Puccinia spp) } \\
\text { Botrytis (Botrytis cinerea Fr.) }\end{array}$ & $\begin{array}{l}1,1 \\
2,0 \\
\end{array}$ \\
\hline
\end{tabular}

\section{Conclusions}

Berberis thunbergii DC., Physocarpus opulifolius L. и Weigela florida DC. A comprehensive analysis of the life state of flowering shrubs grown using various technologies made it possible to highly appreciate biologic techniques in the technologies for the production of ornamental crops, identified the most resistant species in a modern city: Berberis thunbergii DC., Physocarpus opulifolius L. and Weigela florida DC.

In the course of a phytosanitary survey, an assessment of the damageability of flowering shrubs by entomo- and phytopathogenic objects in an urbanized environment was carried out. Identified pests that damage various plant organs; noted non-infectious diseases, as well as infectious diseases caused by fungi and viruses: Aphis spiraephaga и Tetranychus urticae; Sucking pests were the predominant phytophages: Aphis spiraephaga and Tetranychus urticae; noncommunicable diseases: necrosis, chlorosis and leaf curling: infectious: spots, powdery mildew, peronosporosis. High resistance to harmful objects is typical for Chaenomeles japonica (Thunb.) Lindl.), Physocarpus opulifolius L., Potentilla fruticose L. and Sorbaria Sorbifolia L.

Thus, the studies carried out revealed a high positive fertilizing effect of the use of vermicompost, immunomodulatory effect of biologically active substances (Mival-Agro, 
Novosil, Fitoverm, Alirin-B), and, as a consequence, the formation of an adapted assortment of flowering shrubs for the conditions of urban ecosystems.

\section{References}

1. R. Oladi, M. Emaminasab, D. Eckstein, Dendrochronologia, 44, 94-102 (2017). https://doi.org/10.1016/j.dendro.2017.04.004

2. B. Prévosto, M. Helluy, J. Gavinet, C. Fernandez, P. Balandier, Agricult. For. Meteorol., 282-283, 107856 (2020) https://doi.org/10.1016/j.agrformet.2019.107856

3. C. Cooper Marcus. In: A.S. Devlin (eds) Environmental Psychology and Human WellBeing, (Academic Press, 387-413, (2018). https://doi.org/10.1016/B978-0-12-811481$\underline{0.00015-9}$

4. F. Xue, Z. Gou, S.S.Y. Lau, Sustain. Cities Soc., 34, 114-125 (2017). https://doi.org/10.1016/j.scs.2017.06.014

5. R. Moreno-Salazar, I. Sánchez-García, W. Chan-Cupul E. Ruiz-Sánchez, H.A. Hernández-Ortega, J.Pineda-Lucatero, D. Figueroa-Chávez, Sci. Hortic., 261, 108950 (2020). https://doi.org/10.1016/j.scienta.2019.108950

6. M.L. Gullino, M.L. Dogtry, A. Garibaldi, W.H. Elmer, Crop Prot., 73, $50-59$ (2015). https://doi.org/10.1016/j.cropro.2015.01.003

7. D.W. Hold, In; D.W. Held (eds) Urban Landscape Entomology, (Academic Press, 81106, 2020). https://doi.org/10.1016/B978-0-12-813071-1.00005-1

8. B.F. Nero, B.B. Campion, N. Agbo, D. Callo-Concha, M. Denich, Procedia Eng., 198, 99-115 (2017) https://doi.org/10.1016/j.proeng.2017.07.164

9. A. Parra, R. Zornoza, E. Conesa, A. Faz, M.D. Gómez-López, Ecol. Eng., 109 (Part A), 25-34 (2017) https://doi.org/10.1016/j.ecoleng.2017.08.027

10. M. Ruett, C. Whitney, E. Lüdeling, J. Clean. Prod., 271, 122653 (2020). https://doi.org/10.1016/j.jclepro.2020.122653

11. L. Huché-Thélier, V. Guérin, S. Charpentier, Sci. Hortic., 107(3), 297-305 (2016). https://doi.org/10.1016/j.scienta.2005.08.002

12. G. C. Ciftcioglu, S. Ebedi, K. Abak, Ecol. Indic., 102, 278-288 (2019). https://doi.org/10.1016/j.ecolind.2019.02.048

13. G. Richnau, J. Brunet, A. Busse Nielsen, B. Wiström, Urban For. Urban Green., 17, 158 165 (2016). https://doi.org/10.1016/j.ufug.2016.04.009

14. C. Potter, J. Urquhart, For. Policy Econom., 79, 61-68 (2017). https://doi.org/10.1016/j.forpol.2016.06.024

15. C. Lecomte, C. Alabuvette, V. Edel-Hermann, F. Robert, C. Steinberg, Biological control, 101, 17-30 (2016). https://www.sciencedirect.com/science/article/ abs/pii/S1049964416301074 